\title{
The First Experience of Clinical Practice on Psychology Students' Imaginary ${ }^{1}$
}

\author{
Sueli Regina Gallo-Belluzzo² \\ Elisa Corbett \\ Tânia Maria José Aiello-Vaisberg \\ Pontifícia Universidade Católica de Campinas, Campinas-SP, Brazil
}

\begin{abstract}
Considering the academic development of the psychologist as a complex process which articulates the transmission of scientific knowledge and changes in imaginative activity, we psychoanalytically investigate the collective imaginary of Psychology students regarding the first clinical consultation. We conducted a group interview with 52 undergraduate students, using the Thematic Story-Drawing Procedure as a way to open a dialogical field. The material obtained, through the psychoanalytical method, resulted in the creation/gathering of four affective-emotional meaning fields: "I came, I saw and I conquered", "I know that I (do not) know", "I survived and I will save" and "I am and I do", from which we see an emotionally immature imaginary about the meeting with the patient, since students are more self-centered than concerned with the patient. The overall situation indicates the need for care regarding student academic development, in order to encourage a more mature approach toward the suffering of the other.
\end{abstract}

Keywords: professional education, psychology education, collective imaginary, psychoanalysis-methodology

\section{O Primeiro Atendimento Clínico no Imaginário de Estudantes de Psicologia}

Resumo: Considerando a formação do psicólogo como um processo complexo, que articula transmissão de conhecimentos científicos e mudanças na atividade imaginativa, investigamos psicanaliticamente o imaginário coletivo de estudantes de Psicologia sobre o primeiro atendimento clínico. Realizamos entrevista grupal, da qual participaram 52 graduandos, usando o Procedimento de Desenho-Estória com Tema como favorecedor da abertura de um campo dialógico. O conjunto das produções foi considerado através do método psicanalítico, resultando na criação/encontro de quatro campos de sentido afetivo-emocional: "vim, vi e venci", "sei que (não) sei”, "sobrevivi e salvarei" e "sou e faço", a partir dos quais percebemos um imaginário emocionalmente imaturo sobre o encontro com o paciente, uma vez que os alunos se mostram mais centrados em si mesmos, do que preocupados com o paciente. O quadro geral indica a necessidade de cuidados em relação à formação do aluno, no sentido de facilitar uma aproximação mais amadurecida do sofrimento do outro.

Palavras-chave: formação profissional, ensino da psicologia, imaginário coletivo, psicanálise-metodologia

\section{La Primera Experiencia de la Práctica Clínica en el Imaginario de Estudiantes de Psicología}

\begin{abstract}
Resumen: Considerando la formación académica del psicólogo como un proceso complejo, que articula transmisión de conocimientos científicos con cambios en la actividad imaginativa, investigamos psicoanalíticamente el imaginario colectivo de estudiantes de Psicología sobre la primera experiencia de la práctica clínica. Realizamos una entrevista grupal, que incluyó 52 estudiantes universitarios, utilizando el Procedimiento Dibujos-Cuentos con Tema para favorecer la apertura de un campo dialógico. El material obtenido fue considerado a través del método psicoanalítico, resultando en la creación/encuentro de cuatro campos de sentido afectivo-emocional: "vino, vio, conquistó", "Yo sé que (no) lo sé", "sobreviví e salvaré" y "soy y hago". Percibimos un imaginario emocionalmente inmaduro sobre el encuentro con el paciente, puesto que los alumnos están más centrados en sí mismo que preocupados por el paciente. El panorama general indica la necesidad de atención a la educación de los estudiantes, para facilitar un enfoque más maduro del sufrimiento de otro.
\end{abstract}

Palabras clave: educación profesional, enseñanza de psicología, imaginario colectivo, psicoanálisis-metodología

This study is part of a set of works that, from quite varied designs regarding the theoretical-methodological perspective, thematize the academic development of psychologists. Among the pioneering studies dealing with the profile of the profession that have produced contributions

\footnotetext{
1 Support: National Council for Scientific and Technological Development $(\mathrm{CNPq})$ and Coordination for the Improvement of Higher Education Personnel (CAPES).

2 Correspondence address:

Sueli Regina Gallo-Belluzzo. Pontifícia Universidade Católica de Campinas. Avenida John Boyd Dunlop, $\mathrm{s} / \mathrm{n}^{\circ}$. Jardim Ipaussurama. CEP 13060-904. Campinas-SP, Brazil. E-mail: suelibelluzzo@gmail.com
}

of great relevance, we highlight Bastos (1990), Botomé (1979), Carvalho (1982, 1984) and Mello (1972, 1975). In addition to these, historical works that considered the emergence and development of the profession in Brazil should not be forgotten. These are well represented by contributions such as those of Antunes (1998), Guedes (1996), Massimi and Guedes (2004), Pessoti (1988) and Soares (1979). The importance of such investigations lies in the effective concern of these professionals with the social effects that this area of knowledge and the practices that are based on it generate together with the population of this country. 
Among the productions that are directly aimed toward the consideration of specific moments in the academic development of psychologists, it is worth remembering those of Babbage (2008), Gonsalvez, Hyde, Lancaster and Barrington (2008) and Lewis, Hatcher and Pate (2005), which rigorously addressed the importance of the university clinic and the supervision in the professional development of psychologists. We also highlight the studies of Aguirre et al. (2000), Aiello-Vaisberg (1999) and Moratto (1989) who, from different methodological perspectives, presented pedagogical proposals to deal with the affective-emotional aspects of the students that emerge in the first contacts with patients.

Studies of this nature are also made in other areas and not just in Psychology, as can be seen by consulting the recent literature (Black et al., 2010; Carvalho, Pelloso, Valsecchi, \& Coimbra, 1999; Charleston \& Happell, 2005; Hung, Huang, \& Lin, 2009; Skoien, Vagstol, \& Raaheim, 2009; Tully, 2004; Yang et al., 2011). This is an issue that interests us deeply both because we attach fundamental importance to the university academic development process of the psychologist, and because of the fact that, from our point of view, this research clearly harmonizes with what the postgraduate program in which we work proposes in terms of its area of concentration: Psychology as a Science and Profession.

We consider that the pedagogical work in the context of the academic development of the psychologist is not only to convey information about how to perform a psychological consultation, but also to encourage a more authentic and spontaneous approach of the student with their patient. To teach students to conduct a clinical consultation is not just to provide them with a theoretical basis, but to prepare them to deal with relationships between people, inter-human encounters, those which involve the unique personality of the professional.

Psychology students have, in their imaginary, well established beliefs, images and fantasies about the meeting between the psychologist and the patient (Aiello-Vaisberg, 1999). In fact, the students come to the higher education course with opinions and expectations that they derive from their previous experience, which will always be imaginatively constructed. As the human experience always occurs, from our point of view, in a dialectical relationship with the social environment in which we live, we comprehend that the students who will perform their first clinical consultation share socially circulating ideas, images, beliefs, values and fears, in relation to the experience of being alone with their patient, despite what they have learned in the theoretical disciplines.

Our proposal is therefore to investigate the imaginary of these students regarding the clinical consultation before they are alone with their patient and to comprehend it psychoanalytically, that is, from a perspective that values this human behavior that emerges from affective-emotional, conscious and unconscious configurations. The concept of imaginary is conceived here as the ideo-affective complex, a phenomenon of the behavior that occurs in the context of intersubjectivity, in order to give the due value to the emotional-affective substrate of the symbolic manifestations, sustainers of the networks of meanings that influence the actions in the world. We refer both to the imaginary conduct itself as well as to its product, i.e., the human environment, which presents itself as a collection of images, beliefs, values, etc. (Aiello-Vaisberg \& Ambrósio, 2006; Aiello-Vaisberg \& Machado, 2008; Bleger, 1963/1984).

We consider that the psychoanalytic investigation of the collective imaginary of students regarding the clinical consultation may facilitate the production of knowledge that provides benefits in interventional and psychoprophylactic terms. In interventional terms, we consider that this study could benefit professors and students involved with supervision and patient consultations. In preventive terms, comprehending that some of these ideas, beliefs, fears, etc., may need to be transformed can also be beneficial to students and their patients, aiming for a more ethical, inclusive and creative professional practice.

We think that the supervision space must perform the same functions as the environment that is good-enough in childhood, encouraging well-being through respect for the pace of emotional development of the individual (Aiello-Vaisberg \& Granato, 2006; Couto, Tachibana, \& Aiello-Vaisberg, 2007; Granato \& Aiello-Vaisberg, 2009). Considering the above, this study aimed to psychoanalytically investigate the collective imaginary of psychology students regarding the first clinical consultation.

\section{Method}

\section{Participants}

The participants of this study were 52 students from the $7^{\text {th }}$ semester of the Psychology course of a private university in the state of São Paulo, who were attending the Psychodiagnostics discipline. We only asked them to identify their age and gender. There were 41 females, 10 males and one person who did not provide the requested identification. Ages ranged from 20 to 49 years, with the majority in the 20-29 years age group. The undergraduate students were taken as a single collective personality: "The Psychology student". These students had already performed observational practical activity, accompanied by a professor, in the Basic Fieldwork module. In the Psychodiagnostics discipline, they assume the professional function, when they conduct the first clinical consultation alone with the patient.

\section{Procedure}

Data collection. Following the research tradition that values group meetings (Duchesne \& Haegel, 2005), we use the differentiated research framework called "group interview to approach the collective personality" (Avila, Tachibana, \& Vaisberg, 2008; Corbett, 2009; Martins, 2007). This framework is organized around the use of the Thematic 
Drawing-Story Procedure, which was developed by AielloVaisberg (1999), from the diagnostic instrument designed by Trinca (1976). This consists of the request for the participant to individually draw a person who lives in a certain situation, then, to invent and write a story about the figure drawn. To carry out this study, we chose as the theme for the drawing and the story "a student Psychology in his/her first clinical consultation". Considering that the stories were written by the students, when we introduce them, we respect the grammatical form that was used.

Data analysis. The productions of the students were analyzed using the psychoanalytic method. The material was considered by the researcher, seeking to exempt herself from criticism or attachment to beliefs and theories, corresponding to floating attention (Aiello-Vaisberg \& Machado, 2008; Silva, 1993). It was subsequently presented to the members of the research group to which we belong, with the aim that multiple views could, from points of tension, dissonance and resonance, broaden the view about the communications of the students, enhancing the comprehension and interpretation of the emotional experiences of the students.

We therefore seek to identify the affective-emotional fields, or relative unconscious, from which the drawingsstories emerged when contemplated from psychoanalytic perspectives. It is worth explaining that we use the adjective "relative" to indicate a comprehension of the unconscious as a psychic dimension that is always relative to specific manifestations of behavior. We followed the steps recommended by Herrmann (1991, p. 180), who distinguishes three phases of the methodological process: "to let it emerge", "to take into consideration" and "to complete the design". Note that the first phase, "to let it emerge"," comprises, from our point of view, both the person's own production of the drawings-stories, from the imaginative activity of the students in the encounter with the theme, as well as our own associations, the fruits of our imaginative activity, faced with the clinical material. Regarding the third phase, we prefer the expression "to create/encounter" affective-emotional fields, or relative unconscious, because we did not intend to complete the drawings made by the students with a meaning that was latent, but to engage with the material produced by the students, giving it new meaning.

\section{Ethical Considerations}

The research project was approved by the Ethics Committee for Research with Human Subjects of the Pontificia Universidade Católica de Campinas (protocol 284/09). The participants authorized the use of their productions by signing the Terms of Free Prior Informed Consent.

\section{Results}

The psychoanalytic consideration of the productions allowed us to create/encounter, or interpret, from the perspective of Herrmann (2001), four different fields, according to those which organize the imaginary of these students: "I came, I saw and I conquered", "I know that I (do not) know", "I survived and I will save" and "I am and I do". The field that we identified as "I came, I saw and I conquered" is organized by the belief that the value of the clinical consultation fundamentally consists of the personal realization of the student. The consultation of the patient is considered a task included more in the academic development of the student than in the clinic itself, being therefore understood as academic work, and not as professional practice. The students are focused on their performance and personal fulfillment, leaving the patient in the background, to the extent that the urgencies or needs of the students are compelling and require results in a highly competitive context.

As an example of the production that is found within this field, we have a drawing of a young woman sitting behind a desk, on which there is a vase of flowers and a book with the Psychology symbol. The young woman has a series of questions around her head. There are two chairs beside the table and a door that reads "Waiting Room". An excerpt from the story accompanying this drawing is as follows:

[...] the anguish and anxiety were dominating her, as well as a lot of doubt as to how the consultation would go and what would be encountered in the relationship of the family who were waiting behind the door of the waiting room, what kind of behavior would she encounter. Even with all these anxieties Ana wore a beautiful smile on her face, due to arriving at this point and being able to finally see everything that she had learned and was learning in the university in practice.

Another production that was found within this field has the figure of a young man who is standing behind a table, with his hands resting on it. The young man is smiling. The story accompanying this drawing is as follows:

It is even possible to feel the freshness of the morning. The plants in the place where the consultations will be held gives me the impression of entering a park. Something starting that has been long awaited. It's like I was guided to a road where all the paths of life that I had walked converged. I have no expectations about what I will find; in this moment, just, let me enjoy the moment.

The productions found in this affective-emotional field express anxiety arising from the task of the first clinical consultation and, simultaneously, the pride to be realizing a personal project. The consultation is linked to the person of the student in a narcissistic way, being important due to marking an achievement, i.e., becoming a psychologist. It is narcissism coupled to a "doing", the pride is linked to the idea of competence. In these imaginative productions we perceived that the interest 
or concern for the person seeking help is in the background, with the more present view being of the patient as someone who will make it possible for the student to become a professional.

The affective-emotional field "I know that I (do not) know" is organized from the belief that the Psychology student is not properly prepared for the task of performing a clinical consultation. In this field, the anxiety and fear resulting from the prevailing belief can express themselves both directly, as well as through situations in which the competence displayed, through the figure drawn, possesses a clearly defensive aspect. In the universe of these students, the lack of mastery of the task is considered equivalent to professional failure.

As an example, we can recall the design of a spiky haired boy with his hands placed on each side of the head, who had a plainly frightened and terrified expression on his face. The story that accompanies it is as follows:

Saturday, March 14, 2009, the alarm sounds in Edwardo's room; he gets up, takes a bath and only then remembers that this is his first day of work in the Interclínicas Day Hospital. After the bath, he goes to the kitchen for coffee, but can not eat anything because he is very anxious and worried about this first consultation. His mother tries to reassure him and takes him to the Day Hospital. On the way he even manages to become distracted and talk about other matters, however, upon arriving at the Day Hospital the anxiety and fear increase and he thinks: "Am I really prepared for this now? Will I be able to put into practice everything I learned in the university? Will I be able to make a correct diagnosis of the child? Or will I not be able to do anything and stay silent for 50 minutes? Will I be able, will I be able?"

Among those who showed, in their productions, that they had mastered what had been taught, we observed a submissive attitude, to the extent that the competence arises as the capacity to merely reproduce what the professors had transmitted. "I know that I (do not) know" puts the not knowing and openness to creativity in a kind of eclipse. This becomes more serious when what is being taught is the clinical activity, an always new, inter-human encounter. This would therefore be passive learning, as it only reproduces what was taught. Thus, we believe that this field presents the belief that to attend the patient would be linked to noncreative learning, that a good clinical interview is possible when the student can feel secure due to having received and assimilated sufficient theoretical information.

The third field, which we call "I survived and I will save", is organized from the belief that the choice of Psychology as a profession is made by people who have had experiences of suffering, the overcoming of which motivates them to help individuals in distress. In this context, to be a psychologist would be a mission, an idea which probably corresponds to the fantasy that the fact of having escaped death, or overcome experiences of suffering, requires a kind of payment, restitution, indicating difficulty in receiving what would apparently be a "grace achieved". The decision to become a psychologist is explained as a mission to save people, to ease their suffering.

This communication appears in the drawing of a young woman with a lab coat and her arms behind her back. There are two thought bubbles: "I can't wait to start consulting, I am very happy!" and "But, will I be able to attend the patients well? I want to be a good psychologist!" To the right of the drawing there is an open door, where two children can be seen with bubbles containing question marks over their heads. The story accompanying this drawing is as follows:

I always wanted to be a psychologist, when I was a child I was seriously ill with a heart problem and I became disillusioned with the doctor, I managed to overcome the disease with much Faith and support from the people who loved me. However, when we go through something like that as children, we have no real idea about everything that is happening, but everything is saved within our memories, the fears, sadness, feelings of loneliness, the emptiness of being so far from my home, from my bed, for a child this is very striking, even traumatizing. Because of all that, after this period I decided in my heart that I would help people, trying to help them overcome the fears, apprehension, sadness and emptiness that accompany us throughout life. Life for me is very valuable and I want to somehow make a difference for someone, and Psychology is certainly bringing me this knowledge to help the suffering of the soul. I can't wait to put all this into practice, despite feeling insecure, but I will strive to the utmost to be the best I can. (emphasis added in the original text)

The fourth field, called "I am and I do", is articulated from the belief that the psychologist would have powers to cure all the patients, however contains a criticism, raised due to the tone of humor. A man in the clothes and cape of superman appears in a drawing of a superhero with the following story accompanying it:

Where there is mental pain, psychological distress, feelings of oppression there is Psycho-Man. With his interpretative powers he can cure complexes, strengthen damaged egos, and unravel the unconscious at the speed of lightning. There is no depression that can resist his super acceptance. There is no phobia that can withstand his super support. Holding and handling with the force of a thousand behaviorists. Psycho-Man number one enemy of the psychotropic drugs, defender of the weak egos and the oppressed ids.

In a playful way, this production presents motivation that may be present in every psychologist. This field probably 
expresses a defense developed by psychologists to deal with anxiety that arises in every encounter with the patient - an omnipotent type of defense. Does this field depict the initial moment of the profession, which is quickly overcome, or, who knows, are these motivations maintained in the root of the psychological clinic? In how many moments, do we psychologists manage to be with the other, sensitive to their suffering, and in how many do "we act the hero", trying "to be better carers" than the father and mother of the child that exists in every patient?

\section{Discussion}

In his theory of emotional development, Winnicott (1971/1975) states that mature individuals are those who can achieve an existential position in which their own instinctuality and the ability to worry about the other are integrated. From this perspective, the field "I came, I saw and I conquered" is linked to an emotionally immature imaginary, since the rules of emotional-affective meaning that permeate it are essentially directed toward the students themselves, that is, a personal achievement that seems not to include consideration for the patient or seems to include the patient in a secondary way.

This picture seems to reveal the importance of personal psychotherapy for the psychology student, as well as for the professional who will dedicate themselves to the task of attending people who present psychological distress. However, we also understand that greater care regarding narcissistic aspects, in the society in which we live, in which the individual does not seem to feel recognized or valued (Lasch, 1979/1983), favors an emotionally healthy life. Considering the personal aspects of each student and the conditions of the society in which we operate, we believe that to structure the clinical supervision as a space that integrates theoretical knowledge and holding may facilitate the patient care and the professional academic development. Our aim is to promote the proximity of the psychology student to the clinical reality in "small doses" (Winnicott, 1982b), enabling the development of the ability to worry about the other. We do not propose that supervision alone should have a mutative effect, but we believe that the work flows better when the supervising professor can establish an emotional environment conducive to the development of the students' experiences faced with the care of their patients.

The second field captured, entitled "I know that I (do not) know", presented productions that are based in the field of lack of academic preparation. This field highlights the concern of these students that they do not know enough to attend a patient. They present doubts as to whether the course prepared them for this moment. Many discussions take place about the professionals that the universities are forming. However, when it comes to the formation of people who will take care of individuals who are suffering, it is also essential to think about providing conditions for the emotional development of these future professionals. Thus, in addition to the questions about the student's preparation for this moment, we consider it necessary to cover another point: are these students concerned with the fact that they know little because they are considering the needs of the patient, or because, narcissistically, to perform a poor consultation is the same as obtaining a bad grade or failing? The second alternative highlights an imaginary related to narcissistic aspects, with the patient care also being secondary. Concerns with themselves do not open spaces for discovery - the transitional space.

The transitional space was defined by Winnicott (1988a) as an intermediate area, developed by the well-cared-for baby, who was able to undergo the experience of the "illusion". This is preserved by the adult individual, who can always fall back on this when reality presents itself as too painful to be faced, allowing the development of the difficulties encountered, in a more creative contact with the outside world. When the individual has early contact with the real, due to not being protected by illusory experiences, one of the consequences is the exaggerated submission to the data of reality with the establishment of a "false self". There is a loss of spontaneity and authenticity, necessary to establish creative bonds in the relationships with the world (Aiello-Vaisberg \& LousadaMachado, 2005; Winnicott, 1988b).

The third field found, entitled "I survived and I will save", is based on the belief that people who have achieved salvation, who survived the experience of intense suffering, had to "repay the debt", assuming the mission to "alleviating the suffering of the soul" of other individuals. Bleger (1963/1984, p. 145) describes the structures of behavior as "the number of ways in which humans, unitarily considered, can respond or act; all the types of behavior to which they can resort: the repertoire of behavior". The paranoid structure is characterized by the subject identifying or experiencing, in the external world, a persecutory or dangerous object or objects. In paranoid behavior an external object, about which a prior projection of an internal dangerous object has been made, is experienced as dangerous. While in Kleinian thought, the paranoid anxieties are caused by the action of innate destructive impulses, Winnicott considers the environmental failure in early development to be an important factor in the intensification of the paranoid anxieties (Santos, 1999).

In the field "I survived and I will save" we have an example of how the omnipotent fantasy, described by Winnicott (1988a), can manifest itself, when it was not fully experienced because it was not sufficiently supported by the environment. The illness always means an invasion that interrupts the continuity of being and, therefore, the omnipotence. The person who becomes seriously ill symbolizes everybody that "collided" with the real and saw their omnipotence seriously shaken. Therefore, the disease can implode an omnipotent experience that was going well. This field warns that we should pay attention to what motivates the students that are on this course, as this will be reflected in the relationship that will be established with the patient.

The fourth field found in the productions of these students is what we called "I am and I do", which presents the desire, 
which may be in the unconscious of every psychologist, that is, to cure all the patients. This desire is expressed in a playful and humorous way, evidencing a healthy trait of the collective personality with which we are dealing, therefore emerges as a sign of hope that this distressing experience can be really experienced, in the Winnicottian sense.

There is a question: is it natural to start, submerged in anguish about the personal value, about the ability to learn, to escape, to be safe from great problems to which all are subject (illness, loss, frustration, invasions, etc.), however, at the same time to retain a capacity to play with the personal limitation, with our "natural" lack of superpowers? When can we assume this more emotionally mature position? It is a difficult task, especially for those just starting. These last two fields presented are deeper, addressing something that is fundamental: the motivation that directs the option and the exercise of the profession of psychologist. Perhaps a psychologist reveals a fracture in the omnipotence of the baby that we were.

We observed that all the productions contained an anxious structure, which constitutes a defense of the collective personality composed by the group of students, when it lost its ability to react in an organized and coordinated way faced with a danger. This disorganized behavior is "the result of a danger that is already acting as such and is already disrupting the personality" (Bleger, 1963/1984, p. 146). The field "I came, I saw and I conquered" has a narcissistic structure, while the field "I know that I (do not) know" presents itself as obsessive-ritualistic, due to being organized from the idea of acquiring the knowledge to behave correctly. The ritual would have the function of magically nullifying the danger of the persecutory object, in this case, the professor, the colleagues and the patient. The field "I survived and I will save" is organized as the paranoid defense to persecutory anxiety (Bleger, 1963/1984).

The field "I am and I do" seems to be the one in which the inclusion of the other is more clearly perceived. This leads us to conclude that the collective personality has immature traits as well as mature playful traits. We believe that the favorable environmental conditions for healthy development, proposed by Winnicott (1979/1983), can be transposed to other moments of the individual's life, not restricted to childhood. The task of attending the patient presents itself as a new experience, which creates insecurity, fear and anxiety. Thus, we conceive that the work of supervision should not be limited to guidance and encouragement. We propose the development of work similar to that performed by Aiello-Vaisberg (2004) in the Being and Doing Workshops, favoring experiences that allow the omnipotent fantasy to be experienced in a protected way and giving the possible paradoxical condition of madness/sanity, which will configure as the existential playful position, more chance of being achieved. This proposal, called transitional learning frameworks, consists of gradual approaches to the experience of being alone with the patient (Aiello-Vaisberg, 1999).

Based on these fields, we can perceive the outlines of a collective subject that will need psychic or emotional affective aid in its encounter with the patient. Its fears, anxieties and demands reveal suffering, but also clarity about the difficulties it will encounter in this task. Our work as educators is to develop educational frameworks that facilitate dealing with emotional experiences aroused by the encounter with the patient. The good-enough environment in the academic development of psychologists will favor an omnipotent game, that provides hope, strengthens and enlivens, allowing the difficulties to then be faced.

\section{Final Considerations}

We believe that this study, while maintaining its local character, provides contributions to the production of knowledge that may cause resonances and illuminate other human experiences, relative to the initiation of the exercise of the profession. The study is inherently limited due to its qualitative character, in so much as it does not provide generalizations, as it did not aim to test or verify hypotheses. We therefore transit a context that values the concrete historical and social conditions of existence of the people, comprehending that scientific knowledge is produced and fed in the interlocution, when the scientific community debate any topic.

From the affective-emotional fields created/encountered in this study, we observed emotionally immature imaginaries regarding the encounter with the patient, with the inclusion of the other being perceived more clearly only in the fourth field. In other fields the students showed themselves to be more concerned with themselves.

This perceived imaginary refers us to the considerations about the conditions for a student, or a psychologist, to perform good clinical care, which brings us closer to the Winnicottian concept of a good-enough environment. According to Winnicott (1982b), the good-enough environment refers to the favorable physical and psychological conditions, with which individuals exist, adequately fulfilling their needs. From the point of view of the subject, it would basically be a trusting environment. As Winnicott conceived the mother as responsible for the good-enough environment of the newborn, calling her the good-enough mother, we understand that, with respect to the clinical consultation conducted by the student of psychology, the professor would be in charge of providing a good-enough environment. Thus, Ávila et al. (2008, p. 162) proposed the term "a good-enough professor".

Sometimes students present themselves as weak as their patients and in need of special care and attention. They expect the supervising professor to welcome them and help them to confront and overcome the anxieties that arise faced with the new demands at the initiation of the professional activity. The issue arises regarding how we can, as professors, work with the students, providing an good-enough environment that encourages the encounter with the patient. According to 
Winnicott(1979/1983), holding is required so that the mother can be good-enough. Likewise, it is necessary that the supervision work is not restricted to theoretical-technical information, but is a space that offers holding, or emotional support to the students, so that they themselves can sustain their patients.

\section{References}

Aguirre,A.M.B., Herzberg, E.,Pinto, E. B.,Becker,E.,Carmo, H. M. S., \& Santiago, M. D. E. (2000). A formação da atitude clínica no estagiário de psicologia. Psicologia USP, 11(1), 49-62. doi:10.1590/S0103-65642000000100004

Aiello-Vaisberg, T. M. J. (1999). Encontro com a loucura: Transicionalidade e ensino de psicopatologia. Unpublished habilitation thesis. Universidade de São Paulo, São Paulo, SP. Retrieved from http://www.teses. usp.br/teses/disponiveis/livredocencia/47/tde-24022006090139/pt-br.php

Aiello-Vaisberg, T. M. J. (2004). Ser e fazer: Enquadres diferenciados na clínica winnicottiana. Aparecida, SP: Idéias e Letras.

Aiello-Vaisberg, T. M. J., \& Ambrósio, F. F. (2006). Imaginários coletivos como mundos transicionais. In T. M. J. Aiello-Vaisberg \& F. F. Ambrósio (Orgs.), Cadernos ser e fazer: Imaginários coletivos como mundos transicionais (pp. 5-8). São Paulo: IPUSP.

Aiello-Vaisberg, T. M. J., \& Granato, T. M. M. (2006). Ser e fazer na clínica winnicottiana da maternidade. Aparecida, SP: Idéias e Letras.

Aiello-Vaisberg, T. M. J., \& Lousada-Machado, M. C. (2005). Transicionalidade e ensino de psicopatologia: Pensando "aulas práticas" com Winnicott. Passages de Paris, (1), 176-185.

Aiello-Vaisberg, T. M. J., \& Machado, M. C. L. (2008). Pesquisa psicanalítica de imaginários coletivos à luz da teoria dos campos. In J. Monzani \& L. R. Monzani (Orgs), Olhar: Fábio Herrmann - Uma viagem psicanalitica (pp. 311-323). São Carlos, SP: Pedro e João Editores/ CECH-UFSCar.

Antunes, M. A. M. (1998). A psicologia no Brasil: Leitura histórica sobre sua constituição. São Paulo: EDUC.

Ávila, C. F., Tachibana, M., \& Aiello-Vaisberg, T. M. J. (2008). Qual é o lugar do aluno com deficiência? O imaginário coletivo de professores sobre a inclusão escolar. Paidéia (Ribeirão Preto), 18(39), 155-164. doi:10.1590/S0103-863X2008000100014

Babbage, D. R. (2008). Psychology training clinics in Australia and New Zealand: Clinic structure. Australian Psychologist, 43(4), 257-277. doi:10.1080/00050060802413354

Bastos, A. V. B. (1990). Mercado de trabalho: Uma velha questão e novos dados. Psicologia, Ciência e Profissão, 10(2-4), 28-39. doi:10.1590/S1414-98931990000200006
Black, L. L., Jensen, G. M., Mostrom, E., Perkins, J., Ritzline, P. D., Hayward, L., \& Blackmer, B. (2010). The first year of practice: An investigation of the professional learning and development of promising novice physical therapists. Physical Therapy, 90(12), 1758-1773. doi:10.2522/ptj.20100078

Bleger, J. (1984). Psicologia da conduta (E. O. Diehl, Trad.) Porto Alegre: Artes Médicas. (Original published in 1963)

Botomé, S. P. (1979). A quem nós, psicólogos, servimos de fato? Psicologia, 5(1), 1-15.

Carvalho, A. M. A. (1982). A profissão em perspectiva. Psicologia, 8(2), 5-17.

Carvalho, A. M. A. (1984). Atuação psicológica. Psicologia: Ciência e Profissão, 4(2), 7-9. doi:10.1590/S1414-98931984000200003

Carvalho, M. D. B., Pelloso, S. M., Valsecchi, E. A. S. S., \& Coimbra, J. A. H. (1999). Expectativas dos alunos de enfermagem frente ao primeiro estágio em hospital. Revista da Escola de Enfermagem da USP, 33(2), 200206. doi:10.1590/S0080-62341999000200012

Charleston, R., \& Happell, B. (2005). Coping with uncertainty within the preceptorship experience: The perceptions of nursing students. Journal of Psychiatric and Mental Health Nursing, 12(3), 303-309. doi:10.1111/j.1365-2850.2005.00837.x

Corbett, E. (2009). "Até que a morte nos separe" e outros campos do imaginário coletivo de estudantes de psicologia sobre sexualidade (Master's thesis). Retrivied from http://www.bibliotecadigital.puc-campinas.edu.br/

Couto, T. H. A. M., Tachibana, M., \& Aiello-Vaisberg, T. M. J. (2007). A mãe, o filho e a síndrome de Down. Paidéia (Ribeirão Preto), 17(37), 265-272. doi:10.1590/S0103-863X2007000200010

Duchesne, S., \& Haegel, F. (2005). L'enquete et ses méthodes: L'entretien collectif. Paris, France: Armand Colin.

Gallo-Belluzzo, S. R. (2011). O imaginário de estudantes de psicologia sobre o primeiro atendimento clínico: Um estudo psicanalitico (Doctoral dissertation). Retrivied from http://www.bibliotecadigital.puc-campinas.edu.br/

Gonsalvez, C. J., Hyde, J., Lancaster, S., \& Barrington, J. (2008). University psychology clinics in Australia: Their place in professional training. Australian Psychologist, 43(4), 278-285. doi:10.1080/00050060802413529

Granato, T. M. M., \& Aiello-Vaisberg, T. M. J. (2009). Maternidade e colapso: Consultas terapêuticas na gestação e pós-parto. Paidéia (Ribeirão Preto), 19(44), 395-401. doi:10.1590/S0103-863X2009000300014

Guedes, M. C. (1996). História da psicologia: Recurso para formação de pesquisadores e de psicólogos. In R. H. F. Campos (Org.), História da psicologia (pp. 161-170). Rio de Janeiro: Associação Nacional de Pesquisa e PósGraduação em Psicologia.

Herrmann, F. (1991). Andaimes do real: O método da psicanálise (2nd ed.). São Paulo: Brasiliense. 
Herrmann, F. (2001). Introdução à teoria dos campos. São Paulo: Casa do Psicólogo.

Hung, B. J., Huang, X. Y., \& Lin, M. J. (2009). The first experiences of clinical practice of psychiatric nursing students in Taiwan: A phenomenological study. Journal of Clinical Nursing, 18(22), 3126-3135. doi:10.1111/j.1365-2702.2008.02610.x

Lasch, C. (1983). A cultura do narcisismo: A vida americana numa era de esperanças em declínio (E. P. Moura, Trad.). Rio de Janeiro: Imago. (Original published in 1979)

Lewis, B. L., Hatcher, R. L., \& Pate, W. E., II. (2005). The practicum experience: A survey of practicum site coordinators. Professional Psychology: Research and Practice, 36(3), 291-298. doi:10.1037/0735-7028.36.3.291

Martins, P. C. R. (2007). O amante competente e outros campos do imaginário coletivo de universitários sobre dificuldades sexuais masculinas (Unpublished doctoral dissertation). Pontifícia Universidade Católica de Campinas, Campinas, SP.

Massimi, M., \& Guedes, M. C. (2004). História da psicologia no Brasil: Novos rumos. São Paulo: EDUC/Cortez.

Mello, S. L. (1972). Atividades profissionais do psicólogo em São Paulo (Unpublished doctoral dissertation). Universidade de São Paulo, São Paulo, SP.

Mello, S. L. (1975). Psicologia e profissão em São Paulo. São Paulo: Ática.

Moratto, H. T. P. (1989). “Eu-Supervisão”: Em cena uma ação buscando significado sentido (Unpublished doctoral dissertation). Universidade de São Paulo, São Paulo, SP.

Pessoti, I. (1988). Notas para uma história da psicologia brasileira. In Conselho Federal de Psicologia, Quem é o psicólogo brasileiro? (pp. 17-31). São Paulo: Edicon.

Santos, M. A. (1999). A constituição do mundo psíquico na concepção winnicottiana: Uma contribuição à clínica das psicoses. Psicologia: Reflexão e Crítica, 12(3), 603-625. doi:10.1590/S0102-79721999000300005

Silva, M. E. L. (1993). Pensar em psicanálise. In M. E. L. Silva (Coord.), Investigação e psicanálise (pp. 11-25). Campinas, SP: Papirus.

Skoien, A. K., Vagstol, U., \& Raaheim, A. (2009). Learning physiotherapy in clinical practice: Students interaction in a professional context. Physiotherapy Theory and Practice, 25(4), 268-278. doi:10.1080/09593980902782298

Soares, A. R. (1979). A psicologia no Brasil. Psicologia: Ciência e Profissão, 30(No. Esp.), 8-41. doi:10.1590/S1414-98932010000500002

Trinca, W. (1976). Investigação clínica da personalidade: $O$ desenho livre como estímulo da apercepção temática. Belo Horizonte: Interlivros.

Tully, A. (2004). Stress, sources of stress and ways of coping among psychiatric nursing students. Journal of Psychiatric and Mental Health Nursing, 11(1), 43-47. doi:10.1111/j.1365-2850.2004.00682.x

Winnicott, D. W. (1975). O brincar e a realidade (J. O. A. Abreu, \& V. Nobre, Trads.). Rio de Janeiro: Imago. (Original published in 1971)
Winnicott, D. W. (1982a). O bebê como pessoa. In A criança e o seu mundo (A. Cabral, Trad., pp. 83-88). Rio de Janeiro: Guanabara Koogan.

Winnicott, D. W. (1982b). O mundo em pequenas doses. In $A$ criança e o seu mundo (A. Cabral, Trad., pp. 76-82). Rio de Janeiro: Guanabara Koogan.

Winnicott, D. W. (1983). O ambiente e os processos de maturação: Estudos sobre a teoria do desenvolvimento emocional (I. C. S. Ortiz, Trad.). Porto Alegre: Artmed. (Original published in 1979)

Winnicott, D. W. (1988a). Desenvolvimento emocional primitivo. In Textos selecionados: Da pediatria à psicanálise (J. Russo, Trad., pp. 269-285). Rio de Janeiro: Francisco Alves.

Winnicott, D. W. (1988b). Objetos transicionais e fenômenos transicionais. In Textos selecionados: Da pediatria à psicanálise (J. Russo, Trad., pp. 389-408). Rio de Janeiro: Francisco Alves.

Yang, C. P., Leung, J., Hunt, E. A., Serwint, J., Norvell, M., Keene, E. A., \& Romer, L. H. (2011). Pediatric residents do not feel prepared for the most unsettling situations they face in the pediatric intensive care unit. Journal of Palliative Medicine, 14(1), 25-30. doi:10.1089/jpm.2010.0314

Sueli Regina Gallo-Belluzzo is a Ph.D. in Psychology from Pontifícia Universidade Católica de Campinas.

Elisa Corbett is a Ph.D. candidate at the Pontifícia Universidade Católica de Campinas.

Tânia Maria José Aiello-Vaisberg is a Full Professor of the Pontifícia Universidade Católica de Campinas.

Received: Mar. $15^{\text {th }} 2012$

$1^{\text {st }}$ Revision: Jul. $13^{\text {th }} 2012$

$2^{\text {nd }}$ Revision: Oct. $21^{\text {st }} 2012$

Approved: Dec. $22^{\text {nd }} 2012$

How to cite this article:

Gallo-Belluzzo, S. R., Corbett, E., \& Aiello-Vaisberg, T. M. J. (2013). The first experience of clinical practice on Psychology students' imaginary. Paidéia (Ribeirão Preto), 23(56), 389-396. doi:10.1590/1982-43272356201313 